\title{
Arap Dili Kaynaklarında Hadis Rivayetinin Yeri (Hicri ilk Üç Asır Örneği)*
}

\author{
Nilüfer Kalkan Yorulmaz ${ }^{1}$ 이
}

Öz

Fuat Sezgin (ö. 2018) Muhadarât fî Târîhi'l-Ulûmi'l-Arabiyye ve'l-islamiyye isimli eserdeki "Arap-i̇slam İlminde İsnadın Ehemmiyeti" makalesi ve Buhari'nin Kaynakları adlı kitabında, Buhârî’nin (ö. 256/870) el-Câmiu's-Sahîh isimli eserinin özellikle tefsir kitabının Ferrâ'ın (ö. 207/822) Me'âni'l-Kur'ân ve Ebû Ubeyde Ma'mer b. el-Müsennâ'nın (ö. 209/824) el-Mecâzu'l-Kur'ân adındaki çalışmasının bir özeti mahiyetinde olduğunu iddia etmektedir. Fuat Sezgin'in bu tespiti Buhârî́nin eserini oluştururken sadece şifahi kaynaklara değil, aynı zamanda yazılı kaynaklara da dayandığı tezinin temelini oluşturmaktadır. Çalışmamızda ise Fuat Sezgin'in Buhâri'nin Ma'mer b. el-Müsennâ'nın eserinden alıntılar yaptığı yönündeki iddiası genişletilecek ve özellikle hicri ikinci asır Arap Dili eserlerindeki hadis rivayetlerinin hicri üçüncü asır hadis eserlerine intikali tespit edilmeye çalışılacaktır. Böylece mezkur iddiadan hareketle hicri ikinci asırda telif edilmiş olan Arap Dili alanındaki eserlerin ihtiva ettiği hadisler bakımından ilk kaynak olup olmama özelliği ve isnad kullanım usulleri belirlenmeye çalışılacaktır. Bu yapılırken ise öncelikle Arap Dili alanındaki eserler Basra ve Kufe ekolü kaynakları olmak üzere iki ana çerçevede incelenecektir. Ayrıca Arap Dilindeki genel hadis kullanım usulü, hadisle istişhad hususundaki yaklaşım, rivayetin aktarıldığı tarikler ve muhtemel isnadlar, hadis eserleriyle kronolojik olarak karşılaştırmalı bir şekilde ele alınacaktır.

\author{
Anahtar Kelimeler \\ Hadis, Arap Dili, Kütüb-i Sitte, Halil b. Ahmed, Ferrâ
}

\section{The Function of Hadīth Chains in the Arabic Language Sources (First Three Centuries of Islam)}

\begin{abstract}
Fuad Sezgin's (d. 2018) article on "The Importance of Isnad in Arab-Islamic Science" and the book titled Buhari'nin Kaynakları claims that Muḥammad b. Ismāīl al-Bukhārī (d.256/870) -in the tafsīr book- summarizes Yaḥyā b. Ziyād alFarrā's (d. 207/822) al-Ma'āni al-Qur'ân and Abū 'Ubayda Ma'mar b. al-Muthannā's (d. 209/824) al-Macāz al-Qur'ān. The main idea of Fuad Sezgin is that al-Bukhārī did not only rely on oral sources but also on written sources when he created the al-Jāmi al-Șahịh. Therefore, Arabic Language Literature in the first three centuries has to be investigated and compared with al-Kutub al-Sitta to reach a final conclusion. In this article, the claims of Fuad Sezgin will be extended and discussed in this respect. In order to verify the authenticity of these claims, the ahadith and the chain system of the al-Bașra and al-Kūfa Arabic Language books will be determined. If the ahāaīth given in these sources comes before the al-Kutub al-Sitta, this means that we can reach earlier sources about the ahādīth given in al-Kutub al-Sitta. In addition, the method of using the hadith in the these sources, the hadith chains and the possible tariqs will be examined in a chronological and comparative way.
\end{abstract}

\section{Keywords}

Hadīth, Arabic Language, al- Kutub al-sitta, Khalīl b. Aḥmad, al-Farrā’

\footnotetext{
* Bu çalışma 2017 yııında tarafimızca hazırlanan "Hicri Illk Üç Asır Arap Dili ve Belâgatı Kaynaklarında Rivayet Sistemi" isimli doktora tezi esas alınarak hazırlanmıştır.

1 Sorumlu Yazar: Nilüfer Kalkan Yorulmaz (Dr. Öğr. Üyesi), İstanbul Üniversitesi, i̇lahiyat Fakültesi, Temel İslam Bilimleri Bölüm, İstanbul, Türkiye. E-posta: nilufer.yorulmaz@istanbul.edu.tr ORCID: 0000-0002-6191-8072

Atrf: Kalkan-Yorulmaz, Nilufer. "Arap Dili Kaynaklarında Hadis Rivayetinin Yeri (Hicri Illk Üç Asır Örneği).” darulfunun ilahiyat, 30, 'Fuat Sezgin' Özel Sayısı (2019): 19-36. https://doi.org/10.26650/di.2019.30.2.0055
} 


\section{Extended Summary}

In this article Fuat Sezgin's claims about the early written sources of the hadith before the al-Kutub al-Sitta are expanded and discussed according to Arabic Language sources written before the al-Kutub al-Sitta. In order to verify the authenticity of these claims, the ahādīth and the chain system in the al-Bașra and al-Kūfa Arabic Language books are determined. If the ahāāith given in these sources comes before the al-Kutub al-Sitta this means that we can reach earlier sources for some ahādīth except the hadīth books. In addition, the method of using the hadīth in these sources, isnāds, and the possible isnāds are examined in a chronological and comparative way. Therefore there are two main questions in this study. The first is "Does the hadith feature in the Arabic Language Sources" and the second is "With what method did they give a place to the hadith." In order to answer these questions, fundamental and early Arabic Language sources were used such as Halil b. Ahmed's Kitāb al- 'Ayn which represents the Basra School's methods and Yahyā b. Ziyād al-Farrā's al-Ma 'āni al-Qur'ân which represents the al-Kūfa School's methods.

The work titled Kitāb al- 'Ayn of Khalīl b. Aḥmad, the first representative of the Basra school, includes somewhat extensive use of the hadith. Indeed, approximately three hundred and forty one hadīth narratives are included in this work. Of these, two thousand and fifty were narrated only as hadiths, seventy were related to Rasūlullāh and thirty one to the companions. Apart from this, there is no usage of isnād in the work. If we analyse these numbers, we can say that seventy three percent of the narratives are passed only as hadith, twenty one of them refer to the Prophet and six percent of them to the companions.

In this regard, it can be said that only $25 \%$ of the narratives of Khalīl b. Ahmad, conveyed as hadīth, were mentioned in the hadith works before Khalīl b. Ahmad, Therefore, we can say that Khalīl b. Ahmad's work is the first source for many hadìth. In addition, these hadīth, which Khalīl b. Ahmmad described as hadīth, were also conveyed as marfūe and mawkūf in hadīth works after him.

When the isnads of the narratives are examined, it can be seen that narrators come from different regions such as Küfa, Basra, Mecca and Medina. In addition, we can say that there are many hadīths in the work that can be described as șạ̣ị̣ (authentic).

When it comes to the question of how the hadith narratives reached Khalīl b. Aḥmad, we see that there is a common name in most of the isnāds. This name is Ayyūb asSakhtiyānī (d. 131/749), one of the hadīth narrators. Hence he is also the teacher of Khalīl b. Ahmad and can be considered to be the person that Khalīl b. Ahmad, took the hadīth narratives from.

The second source of this study is al-Farrā's al-Ma 'āni al-Qur'ân The most important feature of al-Farrā' is that he includes hadīths with isnād in his book. Indeed, as far as we could determine, there are one hundred and sixty seven narratives of hadith with isnad. 
Adding the ones with isnads, this number reaches four hundred. Approximately seven of these narratives are based on the Prophet, seventy on the companions and the remaining on the next generations such as 'Alqama b. Qays (d. 62/682) Masrūk b. al-Ecdāe (d. 63/9683), Sa '̄id b. Cubayr (d. 94/713), Ibrāhīm al-Nakha'ī (d. 96/714), Mujāhid b. Cabr (d. 103/721), Sulaymān b. Mihrān al-A'mash (d.147/764). If we compare these numbers, it can be seen that four percent of the narratives were based on the Prophet, $41 \%$ on the Companions and $55 \%$ on the next generations.

Looking at the next generation, it can be seen that the work has the isnād system of the Kūfa region. Moreover, the fact that he includes mubham narrators in thirty three and balāg mode in twenty three of the isnāds is a reminder that the isnāds of ahl alra'y are used in the hadīths. Indeed, the ittisāl in the isnāds in this regard are not very important. The same understanding exists in the Kūfa language school. However, an important feature of the Kūfe language school separating them from ahl al-ray is that they include 'Abdallāh b. 'Abbās narratives more than 'Abdallāh Ibn Mas 'ūd. Furthermore, when we look at the numbers of the narratives of the companions, we see that fourteen of them are conveyed from 'Alī, twenty seven from 'Abdallāh b. 'Abbās, eighteen from İbn Mesud, six from Aisha, two from Abu Bakr and two from Omar. If we evaluate these numbers, we see that 23\% was conveyed from 'Alī , 37\% from 'Abdallāh b. 'Abbās, 25\% from 'Abdallāh Ibn Mas' ūd, 9\% from Aisha and the remaining 6\% from Abū Bakr and Omar. But, it is inevitable to say that al-Farrā's hadīth generally is not a first source for hadīth. We can find them with their isnāds in 'Abd al-Razzāq al-Ṣan 'ān̄̄'s book and in the other hadith books before al-Kutub al-Sitta. 


\section{Giriş}

“Arap-İslam İlminde İsnadın Ehemmiyeti” adlı makalesi ve Buhârî̀nin Kaynaklart isimli eserinde Fuat Sezgin, Buhârî'nin (ö. 256/870) el-Câmiu 'sSahîh isimli eserinin tefsir kitabının Ferrâ'ın Me 'âni'l-Kur'ân (ö. 207/822) ve Ebû Ubeyde Ma'mer b. el-Müsennâ'nın (ö. 209/824) el-Mecâzu'l-Kur'ân isimli eserinin bir özeti mahiyetinde olduğunu ifade etmektedir. ${ }^{1}$ Böyle bir tespitin yapılmış olması özellikle hadis alanında hadislerin şifahi veya yazılı kaynağa dayandığ 1 iddialarıyla yakından ilgilidir. Zira bu hususta özellikle Goldizher ${ }^{2}$, Joseph Schacht ${ }^{3}$ ve Juynboll'un ${ }^{4}$ hadislerin yazılı bir kaynağa dayanmadığı ve daha sonraki dönemlerde uydurulduğu yönündeki fikirlerine karşı bir duruş sergileyen Fuat Sezgin ${ }^{5}$ ve Nabia Abott, ${ }^{6}$ Goldziher, Schacht ve Juynboll'un iddialarının temelsiz olduğunu belirtmekte ve hadislerle ilgili mümkün olduğunca erken dönemlere dair yazılı kaynak bulunabileceğini savunmaktadırlar. Bu birbirine muarız iki görüşün ortasında ise hadislerin erken dönemlerden itibaren hem yazılı hem de şifahi kaynaklara dayandığını belirten Scholler ${ }^{7}$ yer almaktadır.

$\mathrm{Bu}$ tartışmalar, temel hadis kaynaklarında bulunmayan veya temel hadis eserlerinin ilk kaynak olma özelliği taşımadığı rivayetlerin diğer ilimlere has kabul edilen kaynaklarda bulunup bulunmadığı sorusunu beraberinde getirmektedir. Zira özellikle ilimlerin birbirinden tam olarak ayrışmadığı ve rivayet dönemi olarak nitelenebilecek hicri ilk üç asırda hadis rivayetlerinin daha sonra ilim dalları halini alan fikıh, arap dili ve tarih gibi alanlara ait eserlerde de yer aldığı görülmektedir. Bu çalışmada da söz konusu eserlerde hadislerle istişhad edilip edilmediği tespit edilip hadis kullanım oranına ve usulüne işaret edilecektir. Bu yapılırken ise eserlerde zikredilen isnadların yapısı, muhtemel isnadların çıkarımı, eserlerin hadisler açısından ilk kaynak olma özelliği taşıyıp taşımadığı gibi hususlar araştırılmaya çalışılacaktır. Adı geçen hususların belirlenmesi özellikle Kütüb-i Sitte eserlerinde yer alan hadislerin daha erken dönem eserlerindeki bir yazılı kaynak tespitinin

1 Fuat Sezgin, Buhâri'nin Kaynaklarl (İstanbul: İbrahim Horoz Basımevi, 1956), 127-158; Fuat Sezgin, "İsnadın Arap Dili ve İslami İlimlerdeki Önemi," çev. Hüseyin Kahraman, Uludağ Üniversitesi İlahiyat Fakültesi Dergisi 5, no. 5 (1993): 301-310.

2 Ignaz Goldizher, Muslim Studies (London: 1971), 2: 19

3 Joseph Schacht, The Origins of Muhammadan Jurisprudence (Oxford: Oxford University Press 1975), 36-37.

4 Gualtherus Hendrik Albert Juynboll, Muslim Tradition (London: Cambridge University Press, 2008), 9-10.

5 Sezgin, Buhârî̀nin Kaynakları,127-158.

6 Nabia Abbott, Studies in Arabic Literary Papyri: Qur'anic Commentary and Tradition (Chicago: The University of Chicago Press, 1967), 2: 6-11.

7 Gregor Schoeler, The Genesis of Literature in Islam (Edinburgh: Edinburgh Press, 2009), 16-30. 
yapılması amacına binaendir. Bunun dışında anılan eserlerdeki hadisler, özellikle Kütüb-i Sitte müelliflerinin yazılı kaynaktan beslendiği iddiasını ortaya koymada yetersiz kalmaktadır. Zira bunun için rivayet benzerliği dışında ek karinelere de ihtiyaç duyulmaktadır. Özellikle Arap Dili alanında eser veren müelliflerin Kütüb-i Sitte isnadlarında yer almaması, isnadlarda yazıya delalet eden herhangi bir rivayet lafzının kullanılmaması gibi hususlar Kütüb-i Sitte kaynaklarının yazılı kaynağa dayandığı yönündeki iddiayı zayıflatmaktadır. Bu sebeple yukarıda da belirtildiği gibi çalışmanın temel amacı hadislerle ilgili yazılı kaynağın daha erken bir döneme taşınıp taşınamayacağını sorgulamaktır.

Çalışma yapılırken Arap Dili kaynaklarında yer alan hadisler özellikle Arap Dili Basra ve Kufe ekolü çerçevesinde incelenecektir. Bu eserlerin temel özelliği Kütüb-i Sitte'den önce telif edilmesi ve alanında günümüze ulaşan ilk eserler olmalarıdır. Basra ekolünde ${ }^{8}$ Halil b. Ahmed'in Kitabu'l-ayn, Kufe ekolünde ${ }^{9}$ ise Ferrâ'in Me 'âni'l-Kur'an isimli eserleri incelenecektir. Bunun dışında kalan hicri ilk üç asırda telif edilmiş Arap Dili kaynakları ise Kütüb-i Sitte ile eş zamanlı veya daha sonra telif edilmeleri sebebiyle kapsam dışı bırakılmıştır. Ancak özellikle bu makalede ele alınan iki isim ve eserleri kendi ekollerinin günümüze ulaşan ilk kaynakları olmalarının yanında yine o ekolün temel özelliklerini taşımaktadırlar. Ayrıca tarafımızca 2017 yılında tamamlanan "Hicri İlk Üç Asır Arap Dili ve Belagatı Kaynaklarında Rivayet Sistemi” isimli doktora çalışması da bu makalenin temel kaynaklarındandır.

8 Basra ekolünde Kütüb-i Sitte kaynaklarından daha önceki eserlerden olan Sibeveyh'in (ö. 180/796) el-Kitâb, Halef el-Ahmer'in (ö. 180/796) Mukaddime fi'n-Nahv, Kutrub'un (ö. 206/822) Kitâbu'l-Ezdâd, Kitâbu'l-Fark, Ebû Zeyd el-Ensârî'nin (ö. 215/830) en-Nevâdir, Asma'î'nin (ö. 215/796) Kitâbu'l-Ezdâd, Kitâbu'l-Fark, Kitâbu'l-Işstihad isimli eserlerinin de bu çalışma kapsamında ele alınması gerekebilir. Ancak bu eserlerde hem çok fazla hadis kullanılmıyor oluşu hem de kullanılan hadislerde Halil b. Ahmed ile aynı metodun benimsenmesi sebebiyle mezkur dilcilerin eserlerinin hadis ilmi bakımından incelenmesi bu çalışmanın kapsamı dışında bırakılmıştır. (Nilüfer Kalkan Yorulmaz, "Hicri İlk Üç Asır Arap Dili ve Belagatı Kaynaklarında Rivayet Sistemi” (Doktora Tezi, İstanbul Üniversitesi 2017), 280-295. Bunun dişında Ebû Osman el-Mâzinî'nin (ö. 248/862) Kitâbu 't-Tasrif ve Ebû Hatim es-Sicistânî’nin (ö. 255/869) el-Müzekker ve'l-Müennes, Kitâbu'l-Ezdâd, Kitâbu'l-Fark isimli eserleri de Kütüb-i Sitte ile aynı dönemlerde telif edilmiş olduklarından çalışmanın kapsamı dışında bırakılmıştır.

9 Kufe ekolünün ilk temsilcisi Kisâ̂̂'dir (ö. 189/805). Ancak Kisâî'nin Me 'âni'l-Kur'ân'ının kendisine nispet problemi bulunmasından dolayı bu çalışmada Ferrâ'nın Me 'âni 'l-Kur'ân isimli eseri esas alınmıştır. Kufe ekolünün bir diğer önemli temsilcisi olan İbn Sikkît'in (ö.244/858) Kitâbu'l-Ezdâd, Kitâbu'l-Elfâz, Islâhu'l-Mantık, Kitâbu'l-Kalb ve'l-İbdâl, el-Maksûr ve'lMemdûd isimli eserleri ise İbn Sikkît'in vefat tarihi itibariyle Kütüb-i Sitte ile yaklaşık olarak eş zamanlı olarak telif edilmiş olduklarından çalışmanın kapsamı dışında bırakılmışlardır. 


\section{Halîl b. Ahmed (ö. 175/792) ve Hadis İlmindeki Yeri}

Halîl b. Ahmed el-Ferâhîdî hicri 175 senesinde 75 yaşındayken Basra'da vefat etmiştir. ${ }^{10}$ Arap dilinde titiz bir imam diye nitelenen Halil b. Ahmed, aruz ilminin kurucusu olarak kabul edilmektedir. ${ }^{11}$ Kendisinin rivayette bulunduğu hocaları arasında Asım b. Ahvel, Osman b. Hâdır, Eyyub es-Sahtiyânî, Avvâm el-Havşeb, Gâlib el-Kattân gibi isimler yer alırken öğrencileri arasında Eyyûb b. Mutevekkil, Hammâd b. Zeyd, Nadr b. Şumeyl, Ali b. Nasr, Sibeveyh, Asma'î, Ahfeş el-Evsat bulunmaktadır. ${ }^{12}$ Ayrıca Halil b. Ahmed'in kendi tabakasındaki Arap Dili alimleri arasında en çok rihle yapanı olduğu bilgisi de kaynaklarda yer almaktadır. ${ }^{13}$

Halil b. Ahmed'in dil ile ilgili hususlardaki güvenilirliği yanında İbn Hibbân tarafından hadis ilminde de sika olarak kabul edildiği görülmektedir. ${ }^{14}$ Ancak Ebû Dâvud'un Halil b. Ahmed'in öğrencisi Hammâd b. Zeyd'den aktardığına göre Halil b. Ahmed Haricilerin bir kolu olan İbâziyye'nin görüşlerini benimsemektedir. Yine aynı kaynakta Ebû Dâvud'un aktarmış olduğu bir başka rivayette Halil b. Ahmed'in annesinin cenazesinde büyük oranda İbâziyye mensubu yer aldığ 1 belirtilmektedir. ${ }^{15} \mathrm{Bu}$ durum sebebiyle her ne kadar kendisiyle ilgili kaynaklarda bidat ehli nitelemesine rastlanmasa da alimlerin Halil b. Ahmed ile ilgili bu hususta bazı çekinceleri olduğunu göstermektedir. Ancak özellikle Basra ehlinin hevâ ehli olduğunu belirten münekkidler, buradaki ehl-i hevâdan Halil b. Ahmed'i hariç tutmaktadırlar. ${ }^{16}$ Öğrencisi Hammâd b. Zeyd, Halil b. Ahmed'in İbaziyye görüşlerini benimsediği ve daha sonra hocası Eyyûb es-Sahtiyânî’nin meclisinde bundan vazgeçtiğini aktarmaktadır. ${ }^{17}$ Konuyla ilgili ansiklopedi maddesini yazan Tevfik Rüştü Topuzluoğlu da onun daha sonra ibaziyye ait görüşlerinden döndüğünü ve özellikle hocası Eyyûb es-Sahtiyânî’nin meclislerine katılmaya başlamasıyla ehl-i sünnet akidesini benimsediğini belirtir. ${ }^{18}$

10 Zehebî, Siyeru A'lâmi'n-nubelâ (Kahire: Dâru'l-Hadis, 2006), 7: 429.

11 İbn Sellâm, Tabakâtu Fuhûli 'ş-Şuarâ, (Cidde: Dâru'l-medenî, ty), I: 22; İbnu'l-Mu'tez, Tabakâtu'şşuarâ (Kahire: Dâru'l-ma 'rife, ty), I: 95; Buhârî, Târîhu'l-kebîr (Hayradabad: Dâru'l-me'ârifi'lOsmaniyye, ty), 3: 199; Tenûhi, Târîhu'l-ulemâi'n-nahviyyin (Kahire: by, 1992), 1: 124; Mizzî, Tehzîbu'l-Kemâl (Beyrut: Müessesetu'r-Risale, 1980), 8: 326-327; Hamevî, Mu 'cemu'l-udebâ (Beyrut: Dâru'l-Garbi'l-İslamî, 1993), 3:1260; İbnu'lKıftî, İnbâhu'r-ruvât (Beyrut: Mektebetu'lunsuriyye, 1424), 1: 376; Zehebî, Siyer, 7: 429.

12 İbn Ebî Hâtim, el-Cerh ve 't-ta'dil (Haydarabad: Dâru'l-me'ârifi'l-Osmaniyye, 1952), 3:380; Buhârî, Târîh, 3: 199; Zehebî, Siyer, 7: 430.

13 M. Sâdık er-Rafi'i, Târihu Adâbi'l-Arab (Kahire, Mektebetu'l-iman, ty), 282-285.

14 İbn Hibbân, Sikât (Haydarabad, Dâru'l-me'ârifi'l-Osmaniyye, 1973), 8:229.

15 Mizzî Tehzîb, 8: 326-333.

16 Mizzî Tehzîb, 8: 326-333.

17 Mizzî Tehzîb, 8: 327.

18 Tevfik Rüştü Topuzluoğlu, “Halîl b. Ahmed,” DİA (İstanbul: Diyanet Vakfı Yayınlanı, 1997), 15: 310. 
Eyyûb es-Sahtiyânî (ö. 131/749) ismi ise Halil b. Ahmed'in hocaları arasında özellikle durulması gerekendir. Zira kendisinin Halil b. Ahmed'in hadis eğitiminde daha sonraki bölümlerde de görüleceği üzere önemli bir yerde durmaktadır. Kaynaklar araştırıldığında da Halil b. Ahmed'in hocalarından biri olduğu görülmektedir. Bunun da ötesinde her ikisinin aynı meclislerde bulunduklarına dair bilgilere de ulaşılabilmektedir. Nitekim Nadr b. Şumeyl'in Halil b. Ahmed'den aktardığına göre حاث النضر بن شميل قال، أخبرنا الخليل بن أحمد قال: سمعت أيوب السختياني يحدّث بحديث فلحن، denilmektedir. Buna göre Halil ve Eyyûb aynı mecliste yer almış ve Halil b. Ahmed, hocası olan Eyyûb es-Sahtiyânî’nin dildeki bir hatasından dolayı onu uyarmıştır.

Bir başka rivayette ise yine Halil b. Ahmed'in öğrencisi Hammâd b. Zeyd'in

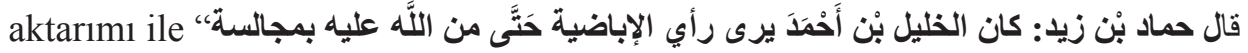
“' 20 أيوب Halil b. Ahmed’in İbaziyye'nin görüşlerini benimsediği daha sonra Eyyûb’un meclisinde bundan döndügünü belirten ifadeler de Eyyûb es-Sahtiyânî ve Halil b. Ahmed'in aynı mecliste bulunduğunu doğrulamaktadır. Dolayısıyla aralarındaki hoca öğrenci ilişkisi, aynı hadis meclisinde bulunduklarına dair elde edilen rivayetler ve Halil b. Ahmed'in eserinde yer verdiği hadislerin temel hadis eserlerinden tahrici yapıldığında Eyyûb es-Sahtiyânî isminin isnadllarda ortak ravi olarak ortaya çıkması veya diğer ravilerle Eyyûb es-Sahtiyâni arasında bir ilişki kurulabilmesi sebebiyle Halil b. Ahmed'in hadis rivayetlerini aldığı en önemli hocasının Eyyûb es-Sahtiyânî olduğu söylenebilir. Ancak hadisçilerin meclisinde bulunduğu ve onlardan ders aldığı halde Halil b. Ahmed'in Kütüb-i Sitte kaynaklarında herhangi bir rivayeti bulunmamaktadır.

\section{Halil b. Ahmed ve Hadisle İstişhad}

Dilde hadislerin istişhad olarak kullanılıp kullanılamayacağı tartışmasının her ne kadar 7. Asırdan sonra başladığı kabul edilse de özellikle hadislerin mana ile rivayet edilmesi ve Arap olmayan ravilerin hadis isnadlarında yer almas1 gibi hususlardan dolayı dille ilgili konularda hadislerle istişhad edilip edilemeyeceği hicri ikinci asırdan itibaren içerisinde farklı yaklaşımları barındıran bir husustur. Özellikle Halil b. Ahmed'in de öğrencisi olan Sibeveyh'in (ö. 180/796) eserinde sadece yedi hadis naklinde bulunması ve bu nakilleri hadis diye isimlendirmeyip mesel diye adlandırıyor oluşu dikkat çekmektedir. ${ }^{21} \mathrm{Bu}$ husus Sibeveyh'in hadisle

19 Hamevî, Mu'cem, I: 23; Mizzî Tehzîb, 8: 328; Zehebî, Siyer, 6: 199.

20 Mizzî, Tehzîb, 8: 327.

21 Sibeveyh, el-Kitâb (Kahire: Mektebetu'l-Hanci, 1988), I: 174, 238, 327; II: 32, 193; III: 268. Nilüfer Kalkan Yorulmaz, "Hicri İlk Üç Asır Arap Dili ve Belagatı Kaynaklarında Rivayet Sistemi," 280-287. 
istişhad konusuna çok sıcak bakmadığını doğrular niteliktedir. Ayrıca Sa leb'in (ö. sünnetin dile hükmedeceği yönünde bir hadisin anlaşılmasında kullandığı söz ve eserinde sıkça hadis istişhadına yer vermes $\mathrm{i}^{23}$ hicri ilk üç asırda hadisle istişhad hususunda olumlu yaklaşımların da bulunduğunu göstermektedir. Suyûtî ise (ö. 911-1505) el-iktitrâh isimli eserinde özellikle konumuzla ilgili olması bakımından Halil b. Ahmed ve Ferrâ' ile birlikte Ebû Amr b. Alâ (ö. 154/771) İsâ b. Ömer es-Sakafî (ö.149/766) gibi Halil b. Ahmed' in hocalarının ve Sibeveyh gibi Halil b. Ahmed'in öğrencilerinin hadisle istişhad yapmadığını ve bu yöntemin daha sonraki müelliflerce de takip edildiğini belirtir. ${ }^{24}$ Ancak Basra ekolünün günümüze ulaşan eserleri bakımından ilk temsilcisi olan Halil b. Ahmed'in Kitabu'l-ayn isimli eserinde hadisleri istişhad olarak kullanmaya önem verdiği görülmektedir. Nitekim eserde yaklaşık olarak 341 hadis rivayeti bulunmaktadır. Bunların 250 tanesi sadece hadis diye nitelenmekteyken, 70 tanesi Rasulullah'a, 31 tanesi ise sahabeye nispet edilmektedir. Bunun dışında eserde herhangi bir sened kullanımına rastlanmamaktadır. $\mathrm{Bu}$ rakamlar kendi içerisinde oranlandığında ise rivayetlerin \%73'ünün sadece hadis diye nitelenerek aktarıldığ1, \%21'inin doğrudan Rasulullah'tan ve \%6'sının yine doğrudan sahabe'den nakledildiği görülmektedir. ${ }^{25}$

Tablo 1. Halil b. Ahmed'in Kullandı ̆̆ Hadislerin Oranı

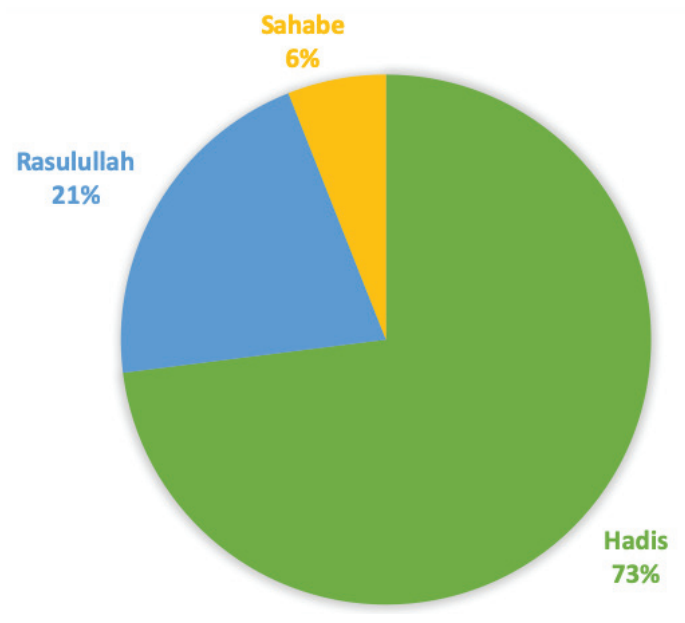

22 Sa'leb, el-Mecâlisu Sa 'leb (Kahire:Dâru'l-Me`ârif, 1980), 40.

23 Yorulmaz, "Hicri İlk Üç Asır Arap Dili ve Belagatı Kaynaklarında Rivayet Sistemi," 488-511.

24 Suyûtî, el-İktirâh (Beyrut: Dâru'l-Beyruti, 2006), 44.

25 Halil b. Ahmed, Kitâbu'l-Ayn (Beyrut: Dâr ve Mektebetu'l-hilal, ty), I: 62, 67, 80, 105, 112, 119, 121, 122, 237, 297; II: 40, 234, 247; III: 5, 8, 9; IV: 48, 54, 110 vd.; Yorulmaz, "Hicri İlk Üç Asır Arap Dili ve Belagatı Kaynaklarında Rivayet Sistemi,” 252-280. 
Zikredilen bu durum Suyûtî'nin aktarmış olduğu bilginin uygulamaya aynı şekilde yansımadığını göstermesi açısından önemlidir. Zira M. Reşit Özbalıkçı tarafından yazılan Arap Gramerinde Kur'an ve Hadis 'in Rolü isimli kitapta ilk dönemlerden itibaren yetişen Arap dilcilerinin hadislerle istişhad yaptıkları savunulmaktadır. ${ }^{26}$ Zira bu durumu daha sonraki başlıklarda görüleceği üzere Halil b. Ahmed'in hadisleri hadis meclislerinden elde etmesi ve bu hususta hadis rivayet sistemine güveniyor oluşu desteklemektedir.

\section{Halil b. Ahmed ve Hadis Rivayetindeki Metodu}

Halil b. Ahmed yukarıda da ifade edildiği gibi eserinde oldukça fazla oranda hadisle istişhadda bulunmaktadır. Ancak bunu yaparken isnad kullanmamakta ve zikretmiş olduğu hadislerin \% 73'ünü doğrudan hadis diye niteleyerek aktarmaktadır. Özellikle giriş kısmında zikredilen Fuat Sezgin'in iddiaları bağlamında düşünüldüğünde burada sorulması gereken üç temel soru bulunmaktadır. Bunlardan birincisi Halil b. Ahmed'in eserinde yer alan hadislerin ne kadarı için Kitâbu'l-Ayn'ın ilk kaynak olma özelliği taşıdığıdır. Zira bu konu Fuat Sezgin'in özellikle temel hadis kaynaklarında yer alan hadislerin daha erken bir dönemde yazılı bir materyale dayandırma çabasının imkanının test edilebilmesini sağlayacaktır.

$\mathrm{Bu}$ hususta Halil b. Ahmed'in hadis diye naklettiği rivayetler incelendiğinde ise sadece \%25'inin Halil b. Ahmed'den önce telif edilen temel hadis eserlerinde yer aldığ 1 görülmektedir. Yani Kitâbu'l-ayn, muhtevi olduğu hadislerin \%75'i için ilk kaynak olma özelliği taşımaktadır. Böylece bu eserlerde yer alan hadislerle ilgili kaynakların daha erken bir döneme dayandırılabildiği görülmektedir. Bununla beraber Halil b. Ahmed'in eserinin bu oranda rivayet için ilk kaynak olma özelliği taşıyor olması hadislerle ilgili yazılı kaynakları daha erken bir döneme çekmekte ancak Fuat Sezgin'in bir diğer iddiası olan Kütüb-i Sitte kaynaklarının ve özellikle Buhârî’nin yazılı kaynaklara dayandığı yönündeki iddiayı doğrulamakta yeterli görünmemektedir. Zira bunun için ek karinelere ihtiyaç duyulmakta ve ikinci temel sorunun sorulması gerekmektedir.

Konuyla ilgili ikinci temel soru ise Halil b. Ahmed'in hadislere hangi tarikler vasıtasıyla ulaştı̆̆ıdır. Zira bu soru bilhassa Basra ekolünün özellikle dil rivayetleri ile ilgili yapılan nakillerde kullanmış olduğu Halil b. Ahmed Ebû Amr b. Alâ ve İsa b. Ömer es-Sakafí $\leftarrow$ İbn Ebî İshak $\leftarrow$ Nasr b. Asım ve Abdullah b. Hurmuz ve Yahya $b$. Ya'mer ve Anbese ve Meymûn Ebû'l-Esved ed-DuelîŁHz. Ali

26 M. Reşit Özbalıkçı, Arap Gramerinde Kur'ân ve Hadisin Rolü (İstanbul: Yeni Akademi Yayınları, 2006), 231. 
Basra isnadının ${ }^{27}$ hadis rivayetlerinde de kullanılıp kullanılmadığının tespitinin yapılmasını sağlayacaktır. Bunun tespitinin yapılması ise özellikle hadislerle istişhad tartışmaları bağlamında düşünüldüğünde Basra ekolünün rivayetleri kendi isnad sistemi içerisinde aktardığı için mi lafzen ve manen güvenilir kabul ettiğini yoksa hadis rivayet sistemi içerisindeki güvenilirliğinden dolayı $\mathrm{m} ı$ aldığının belirlenmesini sağlayacaktır. Şayet Halil b. Ahmed kendi isnad sistemi içerisinde bu rivayetlere ulaşıyor ve eserine alıyorsa daha sonraki Kütüb-i Sitte müelliflerinin bu yazılı kaynaklardan beslenme ihtimali de artmaktadır. Zira kendilerinin katılmış olmadığı meclislerdeki bilgilere yazıılı kaynak vasıtasıyla ulaşmış olabilirler. Bunun aksine Halil b. Ahmed hadisçilerin de içinde bulunduğu ders halkaları vesilesiyle bu rivayetlere ulaşıp eserine aktarıyorsa bu durum, Kütüb-i Sitte müelliflerinin yazılı kaynağa dayandığı yönündeki iddianın doğruluk ihtimalini azaltmaktadır. Nitekim Halil b. Ahmed'in bulunduğu ders halkasında örneğin Buhârî'nin hocasının hocasının da bulunmuş olma ihtimali yüksektir ve bu durum da Buhârî'nin rivayete şifahi bir şekilde ulaşmış olma ihtimalini kuvvetlendirecektir.

Halil b. Ahmed'in eserinde nakletmiş olduğu hadislerin yüz tanesi örneklem olarak alındığında ve bu hadislerin temel hadis kaynaklarındaki isnadları karşılaştırıldığında özellikle bu isnadlarda hoca öğrenci ilişkisi kurulabilen Halil b. Ahmed'in de bizzat meclisinde bulunduğu ve hocası olan Eyyûb es-Sahtiyâni ismi dikkat çekmektedir. ${ }^{28}$ Bu bağlantı kimi zaman doğrudan isnadda Eyyûb es-Sahtiyânî’nin isminin geçmesi vasıtasıyla kimi zaman da Eyyûb es-Sahtiyânî’nin hocaları ve öğrencileri aracılığıyla kurulabilmektedir. ${ }^{29}$ Ancak şu unutulmamalıdır ki bu isnadları Halil b. Ahmed'in bizzat zikretmiyor oluşu konuyla ilgili kesin sonuçlara varılabilmesinin önüne geçmektedir.

Halil b. Ahmed'in hadislere bu isim vasıtasıyla ulaştığı varsayımı kabul edilirse isnadlarda ilgili yapılan incelemeler sonucunda da Halil b. Ahmed'in hadislere sadece Basralı ravilerden değil, Mekke, Medine, Kufe gibi bölgelerden ulaştığı da görülmektedir. ${ }^{30} \mathrm{Bu}$ durum da Halil b. Ahmed'in hadis rivayetlerini kendisine has bir isnad vasıtasıyla almadığına, hadis rivayetinde hadisçilerin metodunu güvenilir olarak kabul ettiğine delil olarak sunulabilir.

27 Kenan Demirayak, Selami Bakırc1, Arap Dili Gramer Tarihi (Erzurum, yy, 2001), 33-45; Yorulmaz, "Hicri İlk Üç Asır," 23.

28 Mizzî, Tehzîb, 8:326-333.

29 Konuyla ilgili isnad incelemeleri için bkz. Yorulmaz, "Hicri İlk Üç Asır Arap Dili ve Belagatı Kaynaklarında Rivayet Sistemi,” 253, 254, 255, 256, 259, 261, 262, 265, 266, 268, 269, 271, $274 \mathrm{vd}$.

30 Yorulmaz, "Hicri İlk Üç Asır Arap Dili ve Belagatı Kaynaklarında Rivayet Sistemi,” 262. 
Özellikle hadislerin yazılı ve şifâhi rivayeti bağlamında Fuat Sezgin tarafından iddia edilen Buhârî'nin Ebû Ubeyde Ma 'mer b. el-Müsennâ'nın Mecâzu'l-Kur'ân isimli eserinden yazılı aktarımlarda bulunduğu iddiası Halil b. Ahmed'in Kitâbu'lAyn'ı bağlamında çok muhtemel görünmemektedir. Zira öncelikle Halil b. Ahmed'in eserinde yer alan hadislerin büyük çoğunluğu için Kitâbu'l-Ayn ilk kaynak olma özelliği taşımaktadır. Bu tespit, Fuat Sezgin'in yazılı hadis rivayetini mümkün olduğunca erken bir döneme çekme iddiasını da doğrulamaktadır. Ancak özellikle rivayetlerin senedleri çıkarıldığında Halil b. Ahmed ve Kütüb-i Sitte müelliflerinin yer yer aynı meclisten rivayetlerini aktarıyor olmaları ve isnadlarda bunun dışında kitabete delalet eden herhangi bir lafzın bulunmaması önemlidir. Bununla birlikte dil ile ilgili hususlarda Basra isnadı dışına çıkmayan ve tüm nakillerini bu vasıtayla yapan Halil b. Ahmed'in hadis rivayetlerinde Medine ve Kufe gibi dil açısından güvenilir kabul etmediği ravilerin rivayetlerine dayanıyor olması da hadis isnad sistemine güvenini ve o kaynaktan beslendiğini ortaya koymaktadır.

Üçüncü ve son soru ise hadislerin metinleriyle ilgilidir. Zira Halil b. Ahmed ve Kütüb-i Sitte kaynakları metin hususunda bir birlik taşıorlarsa bu durum yazılı rivayet iddialarını kuvvetlendirecektir. Ancak metinlerde ihtisarlar veya lafız değişiklikleri bulunuyorsa bu durumda Kütüb-i Sitte müelliflerinin yazılı kaynaktan beslendiği iddiası zayıflayacak ve bu durumda şifahi rivayet argümanı güç kazanacaktır. Konuyu desteklemesi açısından ise Halil b. Ahmed'de yer alan metinlerin birtakım ihtisarlarla veya lafız değişiklikleriyle sadece istişhad için kullanılacak kısmı alınarak aktarıldığı söylenebilir. ${ }^{31}$ Bu durum da Kütüb-i Sitte müelliflerinin yazılı bir kaynağa dayandığı yönündeki iddiaları Halil b. Ahmed özelinde zayıflatmaktadır.

\section{Ferrâ'nın (ö. 207/822) Hadis İlmindeki Yeri}

Ebû Zekeriyya Yahyâ b. Ziyâd b. Abdullah b. Manzûr el-Eslemî el-Ferrâ, Kûfe bölgesi alimlerindendir. Edebiyat ilimleri, lügat ve nahivde alim olarak kabul edilen kişilerdendir. ${ }^{32}$ Kays b. er-Rabî’, Mendel b. Ali, Ebû'l-Ahves, Ali b. Hamza el-Kisâî, Ebû Bekr b. Ayyâş̧, Süfyan b. Uyeyne, Hâzım b. Husayn el-Basrî hocaları arasında zikredilen isimlerdendir. ${ }^{33}$ Öğrencileri arasında ise Seleme b. Asım ve Muhammed b. Cehm es-Simerrî’nin ismi geçmektedir. ${ }^{34}$

31 Yorulmaz, "Hicri İlk Üç Asır Arap Dili ve Belagatı Kaynaklarında Rivayet Sistemi," 254, 255, 256, 257, 259, 260, 261, $265 \mathrm{vd}$.

32 İbn Hallikân, Vefeyâtu'l-a'yân (Beyrut: Dâru's-Sadr, 1990), 7:176.

33 İbn Hallikân, Vefeyât, 6:176; Zehebî, Siyer, 10: 119; İbn Hacer, Tehzîbu'l-Tehzib (Hind: Matbaatu Dâru'l-Me'ârif, 1326), 12: 212-213.

34 Zehebî, Siyer, 10:119; İbn Hacer, Tehzîb, 12:212-213. 
Hadis rivayetindeki yeri ile ilgili olarak ise özellikle muhaddis olarak da tanınan arkadaşı Hennâd b. Serî ile birlikte hadis meclislerinde bulunduklarını görülmektedir. Hennâd, kendisinin özellikle tefsir veya dil konularına müteallik bir hadis işittiğinde bunu hocadan tekrar etmesini istediğini belirtmektedir. Bu durumun ise kendisinde Ferrâ'ın ihtiyacı olan şeyleri ezberlediği zannını uyandırdığını söyler. ${ }^{35}$

Öğrencilerinden Seleme b. Asım ise kitaplarının çoğunu hafızasından imlâ ettiğini belirtirken yine bir diğer öğrencisi olan Muhammed b. Cehm bir kitap hariç kendisinin yazılı herhangi bir şeyi bulunmadığını ifade eder. ${ }^{36}$ Hennâd ve kaynaklarda ismi geçen iki öğrencisinin yaptığı açıklamalar hem Ferrâ’ın hadis meclislerinde bulunduğunu hem de yine hadis ilmi açısından önemli bir mevzu olan hafızasının kuvvetini göstermektedir. ${ }^{37}$ Hadis rivayetinde ise İbn Hibbân tarafından sika bir ravi olarak nitelenmesinin yanında ${ }^{38}$ i'tizale meylettiği ve eserlerinde felsefe yaptığı yönünde olumsuz sayılabilecek ifadeler de bulunmaktadır. ${ }^{39}$ Ancak kendisiyle ilgili herhangi bir cerhe rastlanmamıştır. Arap dili hususunda ise Kufe'de kimse olmasa dahi Ferrâ bu bölgeye yeterdi, Ferrâ olmasaydı Arapça olmazdı gibi yorumlar bulunmaktadir. ${ }^{40}$

Bunanla beraber Buhârî kendisinden iki yerde nakilde bulunmaktadır. Bunlardan birincisi Tefsiru'l-Kur'ân kitabının bab başlığında ${ }^{41}$ diğeri ise Tevhid kitabının bab başlığında yer almaktadır. ${ }^{42}$ Ancak diğer Kütüb-i Sitte kaynaklarında Ferrâ'dan yapılan herhangi bir nakile ulaşılamamıştır.

\section{Ferrâ ve Hadisle İstişhad}

Halil b. Ahmed gibi Ferrâ da hadisle istişhadda bulunmada herhangi bir sakınca görmemektedir. Suyûtî’nin yukarıda zikredildiği üzere Ferrâ'ın da hadisle istişhad

35 İbnu'l-Kıftî, İnbâh, 4: 20.

36 İbnu'l-Kıftî, İnbâh,4: 20.

37 Ferrâ'nın Hudûd isimli eserinin varrâklar tarafından yazıldı ̆̆ı ve Ferrâ hayattayken tasnif edildiğine dair bilgi olmasına karşın bu çalışmada ele alınan Meânî'l-Kur'ân isimli eserinin varrâklar tarafından yazılması hususunda bazı tartışmaların yaşandığı ve sonunda Ferrâ’nın kitabı kendisinin yazacağını söylediği rivayet edilmektedir. Ancak bu kitabın yüz sayfasının Ferrâ tarafından tamamlandığ belirtilirken kalanı ile ilgili herhangi bir bilgi bulunamamıştır. Hatịib el-Bağdâdî, Târîhu Bağdâd (Beyrut: Dâru'l-Ğarbi'l-İslâmî, 2002), 14: 155.

38 İbn Hibbân, Sikât, 9: 256.

39 Zehebî, Siyer, 10: 119.

40 İbn Hallikân, Vefeyât, 6: 176; Zehebî, Siyer, 20:119-120; Tenûhî, Tarih, 1: 187; Ziriklî,el-A'lâm, (Dâru'l- İlm, 2002), 8:145.

41 Buhârî, Tefsîru'l-Kur'ân, 364.

42 Buhârî, Tevhid, 4. 
yapmadığını söylemesine ${ }^{43}$ karşın onun Me âni'l-Kur'ân isimli eseri bu iddiayı doğrulamamaktadır. Öyle ki Ferrâ'dan sonra da Kufe dil ekolü çerçevesinde eser veren İbn Sikkît (ö. 244-858) ve Sa leb (ö. 291/904) gibi isimler dahî hadisle istişhad konusunda Ferrâ ile benzer bir metot takip etmişlerdir.

Ferrâ'y1 Halil b. Ahmed'den ayıran en önemli özellik ise eserinde hadislere isnadlı bir şekilde yer vermesidir. ${ }^{44}$ Nitekim eserde tespit edilebildiği kadarıyla 167 isnadlı hadis rivayeti bulunmaktadır. İsnadı bulunmayan rivayetler de katıldığında bu sayı 400'ü bulmaktadır. Bu rivayetlerin yaklaşık olarak 7'si Hz. Peygamber'e, 69'u sahabeye, geri kalan 91'i ise Alkame b. Kays (ö. 62/682), Mesrûk b. Ecda (ö. 63/683), Sa îd b. Cübeyr (ö. 94/712), İbrahim en-Nehai (ö. 96/714), Mücâhid b. Cebr (ö. 103/721), Âmir b. Şerâhîl eş-Şa bôi (ö. 104/722), Süleyman b. Mihrân el-Ameş (ö. 148/765) gibi daha sonraki nesillere dayanmaktadır. Bu sayılar oranlandığında ise rivayetlerin \%4'ünün Hz. Peygamber'e, \%41'inin sahabeye ve \%55'inin sonraki nesillere dayandığı görülmektedir. ${ }^{45} \mathrm{Bu}$ durum da eserde merfûe ve mevkuf rivayetlerin oranının daha düşük olduğu sonucunu ortaya çıkartmaktadır.

Tablo 2. Ferrầ 'n Kullandığı Hadislerin Dayanakları

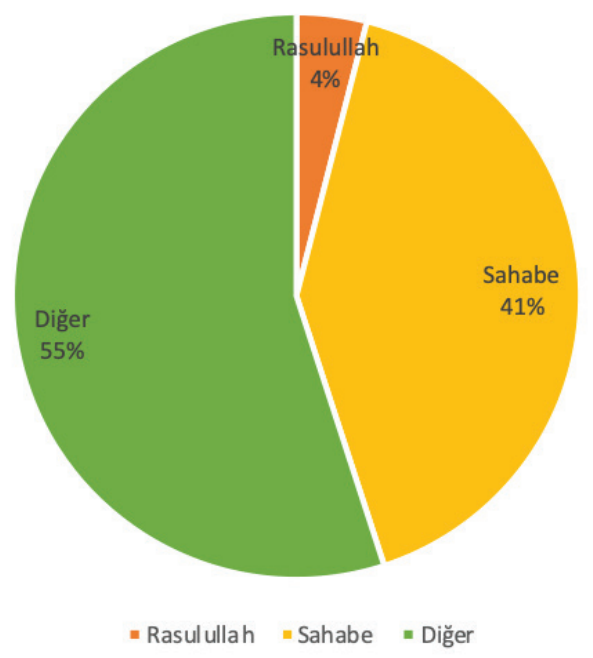

43 Suyûtî, el-íktirâh, 44.

44 Ferrâ, Me 'âni'l-Kur'ân, I, 62, 115,146, 266, 321, 325, 336,406, 440, 468; II, 14, 17, 123, 125 , 132, 262, 327, 382; III, 64, 148, 183, 195 vd.

45 Yorulmaz, "Hicri İlk Üç Asır Arap Dili ve Belagatı Kaynaklarında Rivayet Sistemi,” 337-343. 


\section{Ferra ve Hadis Rivayetindeki Metodu}

Yukarıda da ifade edildiği gibi Ferrâ eserinde isnadlı bir şekilde hadis aktarmaktadır. Ancak bu isnadlar incelendiğinde ise onların, Kufe bölgesi isnad sistemi özelliği taşıdığ1 görülmektedir. Nitekim 167 isnadın 33'ünde mübhem raviye yer vermesi, 23'ünde belâg sigasını kullanması da ehl-i rey'in hadislerde kullandığı isnadları hatırlatmaktadır. ${ }^{46}$ Zira eserde yapmış olduğu isnadlı rivayetlerdeki raviler bölgelerine göre oranlandığında $\% 78$ oranında Kufeli ravilerden aktarılmaktadır. ${ }^{47} \mathrm{Bu}$ durum da Ferrâ'nın Kufe bölgesi isnad sistemini benimsediğini göstermektedir. Ancak Kufe dil ekolünün ehl-i rey'den ayrılan önemli bir özelliği İbn Abbâs rivayetlerine İbn Mes'ûd'dan daha fazla yer vermesidir. Nitekim sahabenin rivayetleri kendi içerisindeki sayılarına bakıldığında 14'ünün Hz. Ali, 27'sinin İbn Abbas, 18'inin İbn Mes êd,, 6'sının Hz. Aişe, 2'sinin Hz. Ebû Bekir ve 2'sinin Hz. Ömer'den nakledildiği görülmektedir. Bu sayıları kendi içerisinde oranlandığında ise \%20 'sinin Hz. Ali'den, \%39'unun İbn Abbâs'tan, \%26'sının İbn Mes 'ûd'dan, \%9'unun Hz. Aişe'den geri kalan \%6'sının ise Hz. Ebû Bekir ve Hz. Ömer'den nakledildiği söylenebilir. ${ }^{48}$

Tablo 3. Ferrâ'ın Rivayette Bulunduğu Sahabenin Birbirine Oranı

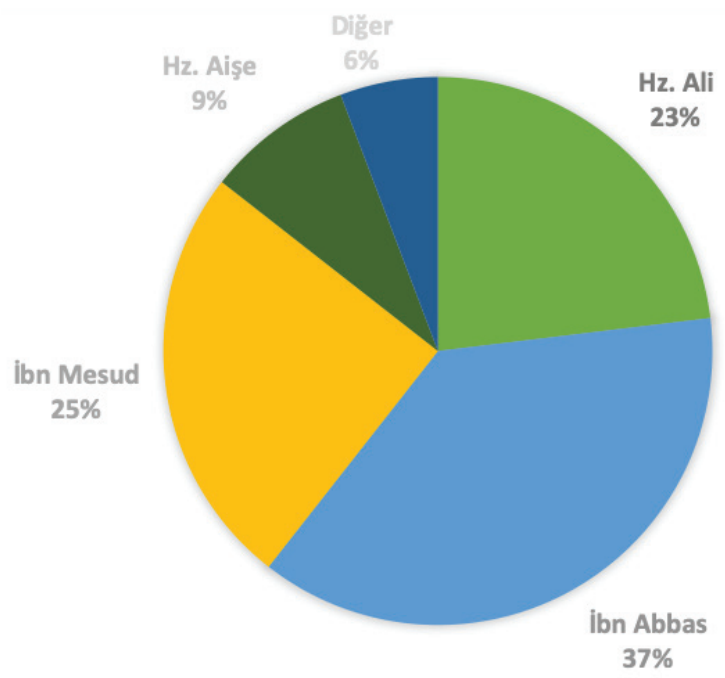

Bu durum da İbn Mes'ud'un daha çok rivayetlerin fikhına ağıllık veren bir sahabi olması sebebiyle İbn Abbâs'dan geride kaldığını akla getirmektedir. Nitekim hem Ferrâ'ın eserinin bir Kur'an sözlüğü olması hem de dil ile ilgili çalışmalarda

46 Nilüfer Kalkan Yorulmaz, Ehl-i Rey'in Rivayet Anlayışı (İmam Muhammed 'in Kitâbu'l-âsâr' Örneği) (İstanbul: Kayıhan Yayınları, 2018), 78-83.

47 Yorulmaz, "Hicri İlk Üç Asır Arap Dili ve Belagatı Kaynaklarında Rivayet Sistemi,” 354.

48 Yorulmaz, "Hicri İlk Üç Asır Arap Dili ve Belagatı Kaynaklarında Rivayet Sistemi," 337-343. 
lafiza daha fazla önem veriliyor oluşu onun İbn Abbâs'1 tercih etme sebebi olarak görünmektedir. ${ }^{49}$

Ferrâ'ın bu hadislere nasıl ulaştığı sorusunun cevabının verilmesi ise Halil $b$. Ahmed'e göre daha kolaydır. Zira kendisinin eserinde isnad zikrediyor olması -her ne kadar muttasıl isnadlar olmasalar da -Ferrâ'n hadislere ulaştı̆̆ 1 raviler hususunda ipuçları sunmaktadır.

Ferrâ'ın eserinde zikretmiş olduğu isnadlara bakıldığında ise hadis rivayetlerini Hibbân b. Alî, İbn Ebî Yahyâ, Abdullah b. Mübarek, Kays b. Rabi`, Mendel b. Ali, Muhammed b. Fazl, Yezîd b. Yezîd, Muhammed b. Ebân, Şerîk b. Abdillah, Süfyân b. Uyeyne, İbn Seleme, Ebu'l-Ahves, Ebû Bekr b. İyaş ve Ebû Muaviye gibi isimlerden aktarmaktadır. Bu isimler arasında Şerîk b. Abdillah (ö. 177/794), Abdullah b. Mübarek (ö. 181/797), Süfyan b. Uyeyne (ö. 198/814) gibi isimler her ne kadar Ferrâ' $n$ hocaları arasında zikredilmese de vefat tarihleri itibariyle muasarât şartını sağlamaktadırlar. Bununla birlikte bu isimlerin Ferrâ'ın arkadaşı olduğunu ve yukarıda zikredilen bilgilerden hareketle aynı mecliste bulunduğunu anladığımız Hennâd'ın hocaları arasında da zikrediliyor oluşu ayrıca dikkat çekmektedir. ${ }^{50} \mathrm{Bu}$ durum da Ferrâ'ın hadis meclislerinde bu hadisleri işittiği iddiasını güçlendirmekte ve hadislerin kendisine şifahi bir şekilde ulaştığı izlenimini vermektedir. Dolayısıyla bu sonuçlar, Fuat Sezgin'in Buhârî'nin Ferrâ'nın Me 'âni 'l-Kur' ân'ından nakillerde bulunduğu yönündeki iddiası desteklememektedir. Zira Ferrâ'nn öğrencilerinden aktarılan bilgilerde yazılı bir materyalinin bulunmadığının belirtilmesi, Ferrâ'ın Abdullah b. Mübârek, Süfyan b. Uyeyne gibi aynı zamanda Buhârî'nin de nakillerde bulunduğu kaynaklardan rivayette bulunması bu iddiayı zayıflatan noktalar olarak değerlendirilebilir.

Hadislerin ne oranda ilk kaynağının Ferrâ olduğu sorusu ise Halil b. Ahmed'de verilen cevapla aynı cevaba sahip değildir. Nitekim Ferra'ın vefatı hicri 207 y1lında olduğundan Ebû Dâvud et-Tayâlisî'nin (ö. 204/819) Müsned'inde, Abdurrezzak (ö. 211/826) ve İbn Ebî Şeybe'nin (ö. 235/849) Musannef'inde aynı muhtevaya sahip pek çok rivayetin nakledildiği görülmektedir. Bu durumun tespiti özellikle Fuat Sezgin'in

49 'Ferrâ'nın Hibbân-Kelbi-Ebû Sâlih-İbn Abbâs tarikiyle nakletmiş olduğu isnad kendisinin özellikle İbn Abbâs rivayetlerini naklederken kullandığı isnaddır. Bu Nitekim eserin yaklaşık otuz beş yerinde Ferrâ bu isnadla nakilde bulunmaktadır. Bu isnadın bir başka tariki ise FerrâEbû Bekir b. Ayyâş-Kelbi-Ebû Sâlih-İbn Abbâs diye iki yerde nakledilmektedir. Zikredilen bu iki tarikin dışında ise Ferrâ İbn Abbâs rivayetlerini naklederken yaklaşık on dokuz farklı isnad kullanmaktadır. Dolayısıyla Ferrâ'nın yukarıda zikredilen iki isnadla yaptığı rivayetlerin oranı \%66'yı bulmaktadır ve kendisinin isnad kullanıma dair önemli ölçüde bilgi verecek niteliktedir." (Yorulmaz, "Hicri İlk Üç Asır Arap Dili ve Belagatı Kaynaklarında Rivayet Sistemi," 454.)

50 Zehebî, Siyer, 11: 465. 
Buhârî'nin yazılı kaynakları arasında Ferrâ'nın Me âni 'l-Kur'ân isimli eserini zikretmesi hususunda biraz daha ihtiyatlı olunması gerektiği sonucunu beraberinde getirmektedir. Bununla birlikte şayet rivayetlerinin içeriğindeki benzerlik dikkate alınacaksa Buhârî'nin yanında Müslim'in ve Tirmizî’nin eserleri de bu hususta oldukça dikkat çekmektedir. Zira Ferrâ'ın eserinde yer alan hadislerin tahrici yapıldığında hadis metinlerine Müslim ve Tirmizî’nin eserlerinde Buhârî'den daha fazla yer verildiği görülmektedir. ${ }^{51} \mathrm{Bu}$ sebeple eserin bu açılardan da ayrıca ele alınması gerekmektedir. ${ }^{52}$ Ferrâ'nın eserinde kullanmış olduğu metinler ile ilgili hususta ise Halil b. Ahmed'in eseri incelenirken varılan sonuçların benzerine ulaşılabilmektedir.

\section{Sonuc}

Hicri üçüncü asırda telif edilmiş olan Kütüb-i Sitte kaynaklarında yer alan hadislerin daha erken dönemde telif edilmiş olan Arap Dili Kaynaklarındaki durumunu incelediğimiz çalışmamızda özellikle Basra ekolünün en önemli temsilcisi olan Halil b. Ahmed'in Kitâbu'l-ayn isimli eserinin pek çok hadis için ilk kaynak olma özelliği taşıdığı görülmektedir. Bu bağlamda hadislerin yazılı kaynağının Kütüb-i Sitte öncesi daha erken bir dönemde de Halil b. Ahmed'de bulunduğu söylenebilir. Ancak Kütüb-i Sitte müelliflerinin ve özellikle Buhârî’nin bu kaynaklardan istifade ettiği yönündeki iddianın geçerliliği hususunda birtakım çekincelerimiz bulunmaktadır. Zira Halil b. Ahmed özelinde düşünüldüğünde çıkarılan muhtemel isnadlardan hareketle kendisinin Eyyûb es-Sahtiyânî'nin meclisinde hadis tedris etmesi ve bu muhtemel isnadlarda dil rivayetlerinin aksine diğer bölge ravilerinden de nakillerde bulunuyor olması, hadislerle ilgili kendisine has bir isnadının bulunmadığını göstermektedir. Bu durum da Kütüb-i Sitte müellifleri ile aynı hadis meclisinden yararlandığını göstermekte ve şifahi rivayet iddiasını güçlendirmektedir. Ayrıca Kütüb-i Sitte kaynaklarındaki metinlerle Halil b. Ahmed ve Ferrâ'nn aktarmış olduğu metinlerdeki ihtisarlar veya lafzi farklılıklar da yazılı kaynak iddiasını zayıflatan bir diğer önemli argüman olarak görünmektedir. Ferrâ'ın eseri bağlamında yazılı kaynağı daha erken bir dönemde düşünme imkanı bulunmamaktadır. Yine de Ferrâ'1n isnadlı

51 Ferrâ'ın Müslim ve Tirmizî'de yer alan rivayetleri için bkz. Müslim, Mesâcid, 197; Müslim, Akdiye, 10; Tirmizî, İlim, 17; Tirmizî, Salat, 14; Tirmizî, Kıraat, 1. Konuyla ilgili daha fazla örnek için bkz. Yorulmaz, "Hicri İlk Üç Asır Arap Dili ve Belagatı Kaynaklarında Rivayet Sistemi," 400-465.

52 Nitekim Müslim'in de yazılı kaynaktan nakiller yapıp yapmadığı hususunda Dilek Tekin tarafından 2015 yılında “Yazılı-Şifâhî Rivayet Bağlamında Müslim'in Eser Sahibi Hocalarından Rivayeti” isimli bir tez yapılmıştır. (Dilek Tekin, "Yazılı-Şifâhî Rivayet Bağlamında Müslim'in Eser Sahibi Hocalarından Rivayeti” (Doktora Tezi, Marmara Üniversitesi, 2015), 1-504. 
rivayet aktarımında bulunması ve Kufe ekolü isnad sistemini benimsemesi de Kütüb-i Sitte'nin yazılı kaynaklarından biri olması ihtimalini zayıflatmaktadır. Zira Kütüb-i Sitte kaynaklarında bu isimlerin rivayetlerine ya hiç ya da bir iki nakille rastlanıyor olması, isnadlarda yer alan ifadelerde kitabete delalet eden bir kaydın bulunmaması gibi durumlar da konuyla ilgili kesin bir yargıya varılmasını mümkün kılmamaktadır. Dolayısıyla Arap Dili eserleri incelendiğinde hadislerle bu kaynaklarda istişhad yapıldığ 1 ve kullanılan hadislerin önemli bir kısmı için özellikle Halil b. Ahmed'in eserinin ilk kaynak olma özelliği taşıdığ1 söylenebilir. Bu bağlamda Halil b. Ahmed'in eserinde yer alan hadis metinleri de ayrı bir çalışmanın konusu olarak incelenmelidir. Bununla birlikte Tirmizî’nin yazılı kaynaklarının araştırılması da yukarıda Tirmizî ile ilgili yapılan iddianın doğrulanması için gereklidir. Zira sadece iki kaynak arasındaki rivayet benzerliği Tirmizî’nin yazılı kaynaklara dayandığını göstermede yeterli değildir. Bilakis bu durumun tespiti için ek karinelere ihtiyaç bulunmaktadır.

Finansal Destek: Yazar bu çalışma için finansal destek almamıştır.

\section{Kaynakça/References}

Abbott, Nabia. Studies in Arabic Literary Papyri: Qur'anic Commentary and Tradition. Chicago: The University of Chicago Press, 1967.

Bağdâdî, Hatib. Târîhu Bă̆dâd. Beyrut: Dâru'l-Ğarbi'l-İslâmî, 2002.

Buhârî, Ebû Abdillah Muhammed b. İsmail b. İbrahim el-Cu'fî. Câmiu's-Sahîh. Daru Tavki'n-Necât, 1422)

Buhârî, Ebû Abdillah Muhammed b. İsmail b. İbrahim el-Cu' fî. Târîhu'l-kebîr. Hayradabad: Dâru'lme'ârifi'l-Osmaniyye, ty.

Demirayak, Kenan, Bakırc1, Selami. Arap Dili Gramer Tarihi. Erzurum, by, 2001.

Dilek Tekin. "Yazıl1-Şifâhî Rivayet Bağlamında Müslim'in Eser Sahibi Hocalarından Rivayeti." Doktora Tezi, Marmara Üniversitesi 2015.

Goldizher, Ignaz. Muslim Studies. London, 1971.

Halil b. Ahmed, Ebû Abdirrahman el-Ferâhîdî. Kitâbu'l-Ayn. Beyrut: Dâr ve Mektebetu'l-hilal, ty.

Hamevî, Ebû Abdillah Şihâbuddîn Yâkut b. Abdillah. Mu'cemu'l-udebâ. Beyrut: Dâru'l-Garbi'lİslamî, 1993.

İbn Ebî Hâtim, Ebû Muhammed Abdurrahman b. Muhammed b. İdris. el-Cerh ve 't-ta'dil. Haydarabad: Dâru'l-me ârifi'l-Osmaniyye, 1952.

İbn Hacer, Ebû'l-Fazl Şihabuddin Ahmed b. Ali b. Muhammed el-Askalânî. Tehzîbu'l-Tehzib. Hind: Matbaatu Dâru'l-Me'ârif, 1326.

İbn Hallikân, Ebûl-Abbas Şemsuddîn Ahmed b. Muhammed b. İbrahim b. Ebî Bekr. Vefeyâtu'l-a 'yân. Beyrut: Dâru's-Sadr, 1990.

İbn Hibbân, Ebû Hâtim Muhammed b. Hibbân b. Ahmed. Sikât. Haydarabad, Dâru'l-me'ârifi'lOsmaniyye, 1973. 
İbn Sellâm, Ebû Abdillah Muhammed b. Sellâm el-Cumâhî. Tabakâtu Fuhûli'ş-Şuarâ. Cidde: Dâru'l-medenî, ty.

İbnu'l-Kıftî, Ebu'l-Hasan Cemâlüddin Ali b. Yusuf b. İbrahim b. Abdilvâhid. İnbâhu'r-ruvât. Beyrut: Mektebetu'l-unsuriyye, 1424.

İbnu'l-Mu'tez, Ebû'l-Abbas Abdullah b. Muhammed el-Mu'tez Billah b. Mütevekkil b. el-Mu'tasım b. er-Reşîd el-Abbâsî. Tabakâtu'ş-şuarâ. Kahire: Dâru'l-ma rife, ty.

Juynboll, Gualtherus Hendrik Albert. Muslim Tradition. London: Cambridge University Press, 2008.

Kalkan Yorulmaz, Nilüfer. "Hicri İlk Üç Asır Arap Dili ve Belagatı Kaynaklarında Rivayet Sistemi." Doktora Tezi, İstanbul Üniversitesi 2017.

Kalkan Yorulmaz, Nilüfer. Ehl-i Rey'in Rivayet Anlayışı (İmam Muhammed'in Kitâbu'l-âsâr'ı Örneği). İstanbul: Kayıhan Yayınları, 2018.

Mizzî, Ebu'l-Haccâc Cemâlüddin Yûsuf b. Abdirrahmân b. Yusuf. Tehzîbu'l-Kemâl. Beyrut: Müessesetu'r-Risale, 1980.

Özbalıkçı, M. Reşit. Arap Gramerinde Kur'ân ve Hadisin Rolü. İstanbul: Yeni Akademi Yayınları, 2006.

Rafi'i, M. Sâdık. Târihu Adâbi'l-Arab. Kahire, Mektebetu'l-iman, ty.

Sa leb, Ebû'l-Abbâs Ahmed b. Yahya b. Zeyd b. Yesâr. el-Mecâlisu Sa 'leb. Kahire:Dâru'l-Me ârif, 1980.

Schacht, Joseph. The Origins of Muhammadan Jurisprudence. Oxford: Oxford University Press 1975.

Schoeler, Gregor. The Genesis of Literature in Islam. Edinburgh: Edinburgh Press, 2009.

Sezgin, Fuat. "İsnadın Arap Dili ve İslami İlimlerdeki Önemi.” çev. Hüseyin Kahraman. Uludağ Üniversitesi İlahiyat Fakültesi Dergisi 5, no. 5 (1993): 301-310.

Sezgin, Fuat. Buhâri'nin Kaynakları. İstanbul: İbrahim Horoz Basımevi, 1956.

Sibeveyh, Ebû Bişr. el-Kitâb. Kahire: Mektebetu'l-Hanci, 1988.

Suyûtî, Ebû'l-Fazl Celâlüddin. el-i̇ktirâh. Beyrut: Dâru'l-Beyruti, 2006.

Tenûhi, Ebû'l-Mehâsin el-Mufaddal b. Muhammed b. Mus 'ir. Târîhu'l-ulemâi'n-nahviyyin. Kahire: by, 1992.

Topuzluoğlu, Tevfik Rüştü. "Halîl b. Ahmed.” DİA, 15:310. İstanbul: Diyanet Vakfi Yayınları, 1997.

Zehebî, Şemsuddin Muhammed b. Abdillah Muhammed b. Ahmed b. Osman. Siyeru A'lâmi'n-nubelâ. Kahire: Dâru'l-Hadis, 2006.

Ziriklî, Ebû Gays Muhammed Hayruddin b. Mahmud b. Muhammed b. Ali b. Fâris. el-A lâm. Dâru'l- İlm, 2002. 